\title{
The Relationship between Bacteriological Quality of Dug-Wells \& Pit Latrine Siting in an Unplanned Peri-Urban Settlement: A Case Study of Langas - Eldoret Municipality, Western Kenya
}

\author{
Charles Muruka ${ }^{1, *}$, Francis Adeniyi Fagbamigbe ${ }^{2}$, Andrew Muruka $^{3}$, John Njuguna $^{4}$, \\ David Odhiambo Otie no ${ }^{5}$, Jack Onyando ${ }^{6}$, Zulekha Saidi Wanjiku ${ }^{7}$, Zablon Onyango ${ }^{8}$, David Wamalwa ${ }^{9}$
}

\author{
${ }^{1}$ Environmental Health and Allied Services, P.O. Box 19185, Kisumu, Kenya \\ ${ }^{2}$ Department of Epidemiology and Medical Statistics, University of Ibadan, Nigeria \\ ${ }^{3}$ Centre for Geographic Medicine, Kenya Medical Research Institute, Kilifi, Kenya \\ ${ }^{4}$ Ministry of Health, Ijara District, Kenya \\ ${ }^{5}$ Kenya Red Cross Society, Nairobi, Kenya \\ ${ }^{6}$ Health systems Associates, Kisumu, Kenya \\ ${ }^{7}$ Ministry of Health, Taveta District, Kenya \\ ${ }^{8}$ Ministry of Health, Provincial Headquarters, Kakamega, Kenya \\ ${ }^{9}$ Project Manager (Maternal Health Project), Amref Kenya, Nairobi
}

\begin{abstract}
This study was carried out in Langas, an unplanned peri-urban settlement in Eldoret municipality in western Kenya. The objective of the study was to determine the bacteriological quality of dug-wells vis-a-vis pit latrine siting. Water samples were collected from each dug-well and the distance between each dug-well to the nearest pit latrine was measured. The MPN technique was used to determine nu mber of faecal colifo rms. The mean distance between dug-wells and pit latrines was $19.664 \mathrm{~m} .34 \%$ of samples had total coliform counts ranging fro $\mathrm{m} 0-99 \mathrm{TC} / 100 \mathrm{ml}$ and $14 \%$ had over $1100 \mathrm{TC} / 100 \mathrm{ml} .82 \%$ of dug-wells had faecal coliforms ranging from $0-99 \mathrm{FC} / 100 \mathrm{ml}$ while only $2 \%$ had $1100 \mathrm{FC} / 100 \mathrm{ml}$. A significant but weak indirect (negative) association between pit latrine distance and level of faecal contamination was detected using the chisquare test. That is, as distance between pit latrine and dug-well increases, the Faecal Coliform count decreases. This could be interpreted as decreasing distance increases the chances/risk for dug-well contamination to occur. Using the Linear Regression model, the minimum distance for dug-well contamination not to occur through latrine seepage was found to be not less than $38 \mathrm{~m}$.
\end{abstract}

Keywords Dug-Wells, Distance To Pit Latrines, Total Coliforms (TC), Faecal Coliforms (FC), Unplanned Peri-Urban Settlement

\section{Introduction}

It is often said that good sanitation improves the quality of life by reducing communicable diseases like childhood diarrhoeas. It also is known that "water is life" and "sanitation is health" However, good sanitation facilities alone are unlikely to decrease the risk of disease transmission unless accompanied by good hygiene practices. This leaves no doubt that the relationships amongst water supply, sanitation and human health are linked intimately[1].

It is a well-known fact that in the largest cities in Africa,

* Corresponding author:

cmuruka@yahoo.com (Charles Muruka)

Published online at http://journal.sapub.org/phr

Copyright (C) 2012 Scientific \& Academic Publishing. All Rights Reserved water and sanitation services are hard pressed to meet the needs of the expanding population[2]. In Eldoret municipality in Western Kenya, an inadequate supply of piped water in peri-urban areas cannot go unnoticed, especially in Langas estate where this study was focused. The state of affairs in Langas is indicated by the springing up of dug-wells, both protected and unprotected apparently without any consideration of their siting with respect to pit latrines. The objective of this study was to determine the degree of faecal pollution of dug-well water and to investigate whether it was correlated to the distance between dug-wells and pit latrines.

We hypothesised that dug-well water in Langas is not contaminated with faecal matter due to latrine seepage. This null hypothesis was adopted because an earlier study in the same area by Asheesh et al.[3] found no correlation between 
dug-well water quality and the distance of dug-wells fromp it latrines. The chi-square test was used to test this hypothes is.

The study involved detecting both total and faecal coliforms in water samples from dug-wells. Total coliforms are a heterogeneous group that includes lactose-fermenters such as Enterobacter cloacae and Citrobacter freundii, which can be found in feces and in the environment as well as in drinking water containing relatively high concentrations of nutrients. Faecal coliforms are thermo-tolerant bacteria that are able to ferment lactose at $44-45^{\circ} \mathrm{C}$; the group includes the genus Escherichia and some species of Klebsiella, Enterobacter and Citrobacter. In most circumstances, concentrations of thermo-tolerant organisms are directly proportional to that of $E$. coli whose source in water supplies must always be faecal contamination[4].

\section{Methods}

\subsection{Study Area}

The study was conducted in Langas, unplanned peri-urban settlement in Eldoret Municipality. It is situated southwest of Eldoret town, about $5 \mathrm{~km}$ from the town centre along the Eldoret-Kapsabet road.

Langas is divided into 4 blocks. The blocks are further subdivided into about 1811 plots. Each plot has between 1 and 30 households. Each household has an average of 6 occupants and occupies an average area of 10 square meters. Very few houses have electricity and most of them are semi-permanent.

The main sources of domestic water are dug wells, which are communal (shared among several households in a plot). There were a total of one hundred (100) dug-wells in Langas at the time of th is study. The main method of excreta disposal is through use of the traditional pit latrine. The area has a high water table.

\subsection{Study Design}

The study involved determining the bacteriological water quality of dug-wells in relation to the siting of pit latrines, followed by thereafter testing and describing the relationship between the two variables.

A convenient sample of fifty (50) hand-dug wells evenly distributed in Langas was chosen for this study. This sample size represents $50 \%$ of all the dug-wells in the study area.

All wells sampled met each of these inclusion criteria: fully protected; the rope for drawing water always left suspended in the well at all times except during the drawing of water. Also, there were to be no obstacles like buildings blocking the straight line from dug well to the nearest pit latrine; and, the well must not have been chlorinated in the past three months.

A grab samp le was collected fromeach dug-well. A string, wiped with a disinfectant (i.e.70\% methylated spirit) was tied around the neck of each sterile sampling bottle which was then lowered into each well without it touching the inside walls of the well. Each sampling bottle was immed iately capped, without the hands coming into contact with its mouth, upon withdrawal of the water sample from the well. The samples were labelled with date, time, sample serial number, and the distance of the well from pit latrine.

The bottled water samples were put into polythene bags and then transported to the laboratory. Each polythene bag contained ice packs to prevent multiplication of microorganis ms. Temperatures in the polythene bags ranged from $-2^{\circ} \mathrm{C}$ to $8^{\circ} \mathrm{C}$. All samples were transported to the laboratory within 1 hour after collection. Samples were maintained at similar temperatures in the laboratory refrigerator before analysis. All samples were analyzed within 24 hours after collection.

Measurements of distance were taken from the foot of the latrine superstructure to the perimeter of the mouth of the well.

Laboratory analysis was performed following the procedures of Collins, Lyne \& Grange[5]. Coliforms were detected by the MPN method as described in Collins, Lyne \& Grange[5]. All the tubes that showed turbidity (i.e. reaction) and gas production constituted positive reaction that indicated presence of coliforms.

\section{Statis tical Analysis}

The null hypothes is for this study was that the siting of pit latrines in Langas does not contribute to the faecal contamination of dug-wells due to latrine seepage.

The chi-square test was then used to test a possible association between dug-well contamination and distance to pit latrine. The chi square for linear trend was also used to determine if the as sociation between dug-well contamination and distance to pit latrine changes as the distance increases. We considered a p-value less than 0.05 as statistically significant. We also estimated Spearman's correlation coefficient and fitted a linear regression line to estimate the dependence of faecal coliform counts on distances between dug-wells and pit latrines.

\section{Results}

This section presents results from the bacteriological analys is of water samples and measurements from dug-wells to the nearest pit latrines.

Table 1. Distance between Dug-Wells and P it Latrines

\begin{tabular}{|c|c|c|}
\hline Distance & Number of Wells & Percent \\
\hline Less than $10 \mathrm{~m}$ & 5 & 10.0 \\
$10 \mathrm{~m}-19.99 \mathrm{~m}$ & 23 & 46.0 \\
20m-29.99m & 20 & 40.0 \\
$30 \mathrm{~m} \&$ Above & 2 & 4.0 \\
Total & 50 & 100.0 \\
\hline
\end{tabular}

Ten per cent (10\%) of the dug-wells were located less than 10 metres from the pit latrines, while $46 \%$ and $40 \%$ were located 10 metres to 19.99 metres and 20 metres to 29.99 metres from $\mathrm{mit}$ latrines respectively. On ly $4 \%$ we re p laced at 30.06 metres or above [Table 1]. Thirty four per cent $(34 \%)$ of the samples had total coliform counts ranging from 
$0-99 \mathrm{TC} / 100 \mathrm{ml}$ and $14 \%$ had over $1,100 \mathrm{TC} / 100 \mathrm{ml}$. Eighty two per cent $(82 \%)$ of the samples had faecal coliforms ranging from $0-99 \mathrm{FC} / 100 \mathrm{ml}$ while only $2 \%$ had $1,100 \mathrm{FC} / 100 \mathrm{ml}$ [Table 2].

The mean distance between dug-wells and closest pit latrine was 19.664 metres while the mean faecal coliform count was $85.41 \mathrm{FC} / 100 \mathrm{ml}$ (table not shown).

Table 2. Total Coliform and Faecal Coliform Counts

\begin{tabular}{|c|c|c|c|c|}
\hline \multirow{2}{*}{$\begin{array}{c}\text { MPN } \\
\text { range }\end{array}$} & \multicolumn{2}{|c|}{ Total coli forms count } & \multicolumn{2}{c|}{ Faecal coliforms count } \\
\cline { 2 - 5 } & No. of & Percentages & No. of & Percentages \\
\hline $0-99$ & 17 & 34 & 41 & 82 \\
\hline $100-199$ & 9 & 18 & 3 & 6 \\
\hline $200-299$ & 8 & 16 & 4 & 8 \\
\hline $300-399$ & 0 & 0 & 0 & 0 \\
\hline $400-499$ & 2 & 4 & 1 & 2 \\
\hline $500-599$ & 0 & 0 & 0 & 0 \\
\hline $600-699$ & 0 & 0 & 0 & 0 \\
\hline $700-799$ & 0 & 0 & 0 & 0 \\
\hline $800-899$ & 0 & 0 & 0 & 0 \\
\hline $900-999$ & 0 & 0 & 0 & 0 \\
\hline $1000-1099$ & 0 & 0 & 0 & 0 \\
\hline 1100 and & 14 & 28 & 1 & 2 \\
\hline Total & $\mathbf{5 0}$ & $\mathbf{1 0 0}$ & $\mathbf{5 0}$ & $\mathbf{1 0 0}$ \\
\hline
\end{tabular}

Table 3. Association between distances between dug-wells and nearest pit latrine and amount of Faecal Coliforms in Dug-Wells

\begin{tabular}{|c|c|c|c|c|}
\hline \multirow{2}{*}{ Distance } & \multicolumn{2}{|c|}{$\begin{array}{c}\text { Mean Faecal } \\
\text { Coliform } / 100 \mathrm{ml}\end{array}$} & \multirow{2}{*}{ Total } & \multirow{2}{*}{$X^{2}=9.652$} \\
\hline & $\begin{array}{c}\text { Below } \\
85.41 *(\%)\end{array}$ & $\begin{array}{l}85.41^{*} \& \\
\text { Above (\%) }\end{array}$ & & \\
\hline Less than $10 \mathrm{~m}$ & $1(2.7)$ & $4(30.8)$ & 5 & \multirow{5}{*}{$\begin{array}{c}p \text {-value } \\
0.022\end{array}$} \\
\hline $10 \mathrm{~m}-19.99 \mathrm{~m}$ & $18(48.6)$ & $5(38.5)$ & 23 & \\
\hline $20 \mathrm{~m}-29.99 \mathrm{~m}$ & $17(45.9)$ & $3(23.1)$ & 20 & \\
\hline $30 \mathrm{~m} \&$ Above & $1(2.7)$ & $1(7.7)$ & 2 & \\
\hline Total & 37 & 13 & 50 & \\
\hline
\end{tabular}

The result of chi-square test for independence between the distance of dug-well from nearest pit latrine and amount of Faecal Coliforms gave chi-square $=9.652$ and a -value of 0.022 . This showed a significant association between the variables (Table 3 ).

The analysis of a further test of chi-square to determine if linear trends exist between the distance of dug-well from nearest pit latrine and amount of Faecal Coliforms found in them is shown in table 4.

Table 4. Measure of linear trend between distances between dug-well and nearest pit latrine and faecal Contamination of dug-wells using the Chi-Square test

\begin{tabular}{|c|c|c|c|c|}
\hline \multirow{3}{*}{ Distance } & \multicolumn{2}{|c|}{$\begin{array}{c}\text { Mean Faecal } \\
\text { Colifom } / 100 \mathrm{ml}\end{array}$} & \multirow{2}{*}{ Total } & \multirow{2}{*}{ Odd Ratio } \\
\cline { 2 - 4 } & $\begin{array}{c}\text { Below } \\
85.41(\%)\end{array}$ & $\begin{array}{c}85.41 \& \\
\text { Above (\%) }\end{array}$ & & \\
\hline Less than $10 \mathrm{~m}$ & $1(2.7)$ & $4(30.8)$ & 5 & 1 \\
\hline $10 \mathrm{~m}-19.99 \mathrm{~m}$ & $18(48.6)$ & $5(38.5)$ & 23 & 0.069 \\
\hline $20 \mathrm{~m}-29.99 \mathrm{~m}$ & $17(45.9)$ & $3(23.1)$ & 20 & 0.044 \\
\hline $30 \mathrm{~m}$ \& Above & $1(2.7)$ & $1(7.7)$ & 2 & 0.25 \\
\hline Total & 37 & 13 & 50 & $X^{2}=3.89, p$-value $=0.04$. \\
\hline
\end{tabular}

We found a $X^{2}=3.89$ and $p$-value $=0.04$. This indicated a linear trend existed between dug-well and nearest pit latrine and that the odd ratio of a dug-well being contaminated in terms of amount of Faecal Coliforms reduced as distance between the dug-wells and nearest pit latrines increased.

Linear Regression Model for Distances between dug-well and nearest pit latrine and Faecal Coliforms $/ 100 \mathrm{ml}$

Using distances between dug-well and nearest pit latrine as independent variable and amount of Faecal Coliforms in dug-wells as the dependent variable, we obtained the linear regression line in equation (1)

$$
\mathrm{c}=130.141-3.383 \mathrm{~d}
$$

where $c=$ faecal coliform count and $d=$ distances between nearest pit latrine and dug-well.

The test of significance of the coefficient of the distance produced $p$-value $=0.074$ while the test of significance of the constant gave $\mathrm{p}$-value $=0.001$.

The fitted regression line showed that every increase of one metre in distance between nearest pit latrine and dug-well will cause a decrease of $3.38 \mathrm{FC} / 100 \mathrm{ml}$ of contamination in the dug-wells. [Figure 1]

More so, from equation (1) above, the fitted regression line gave the distance (d)

$$
d=130.141 / 3.383=38.47 \text { metres }
$$

by setting amount of faecal coliforms (c) to zero. That is, on the average, the minimum distance for such contamination not to occur is approximately 38 metres. Any distance below 38 metres between nearest pit latrine and dug-well will certainly cause contamination to occur.

The result also showed that for a dug-well placed side by side (within less than one metre perimeter) with a pit latrine, the level of contamination in terms of Faecal Coliforms could be as high as $130 \mathrm{FC} / 100 \mathrm{ml}$.

Estimate of Correlation Coefficient for Measure of Association between Distance of Dug-Well from Nearest Pit Latrine and Amount of Faecal Coliform

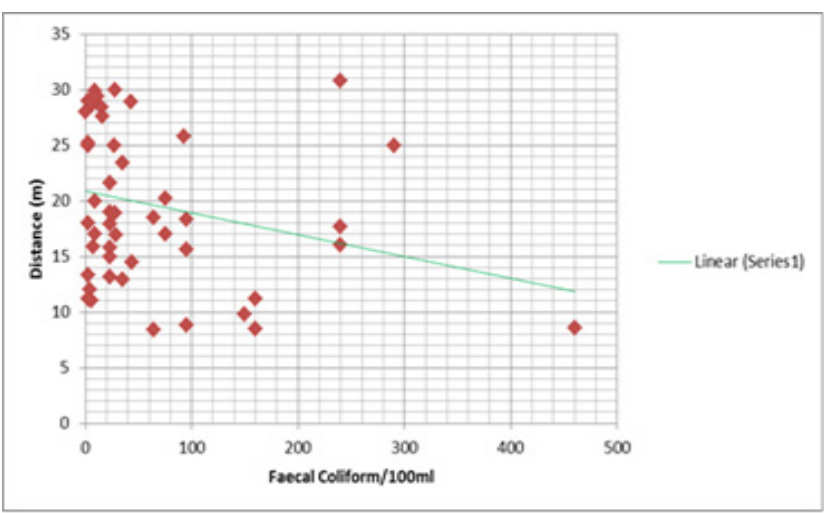

Figure 1. Faecal Coliform counts versus distances between dug-wells \& Pit latrines

Rather than using Pearson's correlation coefficient, we used Spearman's rank correlation coefficient because the assumption of normality has been violated in the data distribution. The distribution of faecal coliform counts in the dug-wells followed an exponential process. We obtained Spearman's rho $=-0.275$ with $p$-value $=0.050$ and the scatter plot of the association between the variables with a fitted linear reg ression line is as shown in Figure 1. We used only 
49 samples for both the regression and correlation analys is by removing sample number 10 from the analys is because its faecal coliform count was estimated to be above $1100 \mathrm{FC} /$ $100 \mathrm{ml}$. We considered this as an outlier.

\section{Discussion}

\subsection{Association between Dug-Well Contamination and Pit Latrine Siting}

In this study, we detected that a significant association existed between distances from dug- wells to nearest pit latrine and that this association between level of dug-well faecal contamination and distance to nearest pit latrines was indirect. For every one metre increase in distance between dug-well and pit latrine, there was a corresponding decrease of $3.38 \mathrm{FC} / 100 \mathrm{ml}$ in terms of contamination.

In a previous study [3] ass ociation was not found between dug-well water bacteriological quality and the distance of dug-wells to nearest pit latrines. They attributed the lack of association to the many possible confounders, e.g. hygiene behaviour, area geomorphology and the presence of other contamination sources. They suggested that once measures to control these other sources of contamination and confounders are in place, the role of latrines in the contamination of well water could then be quantified. However, in the same study, the investigators found that bacteriophages introduced into a latrine that was $31.5 \mathrm{~m}$ from a well were detected 48 hours later in another well that was $63 \mathrm{~m}$ away. This suggests that there is seepage from $\mathrm{pit}$ latrines to well water, despite the fact that no correlation was found between the two variables under investigation.

In our study, we detected an indirect association between level of dug-well faecal contamination and distance to pit latrines. Theoretically, if dug-wells and pit latrines were placed side by side (i.e. within one metre perimeter), the level of faecal contamination would be as high as $130 \mathrm{FC} / 100 \mathrm{ml}$. The null hypothes is that pit latrine siting does not contribute to faecal contamination of dug-wells in Langas, therefore, is disproved.

In the current study, we controlled for contamination of dug-wells due to surface run-off by selecting only protected wells for investigation. Thus, in the absence of any other uncontrolled factors (such as poor hygiene practices by dug-well users), at less than $38.5 \mathrm{~m}$, there is a significant possibility that dug-well water is contaminated by nearby latrines through underground seepage in the Langas. Conversely, at distances greater than $38.5 \mathrm{~m}$, dug-well contamination by faecal coliforms through latrine seepage is not expected. It should therefore be assumed that this is the minimum safest distance between dug-wells and pit latrines in Langas.

This study has also established that the mean distance from pit latrines to dug-wells in the Langas area was $19.664 \mathrm{~m}$, which is quite low compared to the WHOrecommended standard of at least $30 \mathrm{~m} \mathrm{[6]} \mathrm{and} \mathrm{our} \mathrm{detected}$ safest distance of approximately 38 metres.
Out of the fifty (50) water samples taken, $98 \%$ were found to have faecal coliforms ranging from $3 \mathrm{FC} / 100 \mathrm{ml}$ to $1100+\mathrm{FC} / 100 \mathrm{ml}$. Only $2 \%$ of samples had no faecal coliforms. These findings were similar to the earlier findings by Kimani and Ngindu [7] which discovered that 3\% of samples had no faecal contamination whereas $97 \%$ had. Kimani and $\mathrm{Ng}$ indu [7] had also found out that $89 \%$ of the area residents in Langas rely on dug wells as their major source of domestic water and compared to the WHO recommended bacteriological standards of drinking water quality (i.e. a maximum of $1 \mathrm{FC} / 100 \mathrm{ml}$ ), our findings in Langas are worris ome.

Our study showed that most dug-wells were very close to pit latrines. In a 1989 study by German Environmental Consultants in Langas, $54.1 \%$ of the wells were found to be less than $20 \mathrm{~m}$ away from the pit latrines [2]. In yet another study at the same area, $38 \%$ of latrines were estimated to be situated less than less than 15 and most dug-wells (about $59 \%$ ) were estimated to be at a distance between $15 \mathrm{~m}$ and $30 \mathrm{~m}$ from the pit latrines [7]. These previous results were in agreement with the findings our present study, which found out that $56 \%$ of dug-wells were placed at a distance range of less than 20 metres to pit latrines.

\subsection{Recommended Guidelines and Legal Framework for the Prevention of Underground Water Pollution}

According to the WHO guidelines, obvious causes of contamination should be removed from the catchment area, and special attention given to the safe disposal of human excrement. Dug-wells should be protected by lining and covering, diverting surface dra inage, preventing erosion and paving the surrounding area. Fencing should restrict human and animal access and the source should be so designed that fouling does not occur when water is drawn [8].

In addition to the WHO guidelines, there are legal provisions in Kenya's public health laws addressing the same issue. The Water Act Cap 372, section 158(1) states that "any person who by any act or neglect, causes any source of water supply, the water from which is used or is likely to be used for human consumption or domestic purposes, or for manufacturing food or drink for human consumption, to become polluted, or to be likely to be polluted, shall be guilty of an offense" [9]. Thus, the law protects underground water sources, including dug-wells, from contamination. This could be used for legal redress when the occupant of an adjacent plot locates his pit latrine at an unsafe distance from a dug well in his neighbour's plot.

Also, the Public Health Act Cap 242, Drainage \& Latrine Rules (rules under Section 126) states that "No person shall construct or provide latrine accommodation of the kind known as pit closet or latrine accommodation situated over any hole or excavation in the ground which hole or excavation is intended for the reception of human excreta, except where, in the opinion of the local authority, the site of such proposed accommodation and the character of the soil are in every respect suitable and satisfactory for such a purpose, and the local authority has signified its approval 
thereof in writing, and then only subject to such conditions as the local authority may prescribe" [10]. Local authorities thus have an important role in approving the distance between latrines and dug-wells in any area (including unplanned settlements such as Langas) under their jurisdiction. Under no circumstances should any local authority neglect this important legal role.

\subsection{Conclusions}

In the Langas, an unplanned peri-urban settlement, where on the average, dug-wells are placed at less than 20 metres from pit latrines; there is an evidence of contamination of dug-wells due to latrine seepage. The fact that $98 \%$ of the sampled dug-wells in Langas had presence of coliforms implies that there was practically no chlorination being done.

The area dwellers did not follow adequate legal provisions in Kenya's public health and environmental laws which could have been used to abate the pollution of underground water. Similarly, the local authorities did not enforce the same laws and regulations.

\subsection{Recommendations}

In geographical areas with the same hydrogeological and geomorphological characteristics as Langas, we suggest that a minimum distance of $38.5 \mathrm{~m}$ between pit latrines and dug-wells could be adopted as a guideline. Th is is justifiable given the fact that it is only the soil characteristics that directly determine whether or not latrine seepage will contribute to contamination of underground water in any given area.

In unplanned settlements such as Langas, the concerned local authority in collaboration with the Ministry of Water should strive to provide an adequately treated piped water supply. If they are unable to fulfil this obligation, they should provide free chlorine to residents for disinfection of dug-wells. Otherwise, if the chlorine is provided at a cost, it is likely that not many of the residents would be able to afford it. Alternatively, local authorities should install water-borne sanitation systems (sewerage) in such areas in which the main source of domestic water is dug-wells.

Routine health and hygiene education should be conducted in low-income communities because they are more predisposed to health problems as a result of prevalent unhygienic and unsanitary conditions. This education should be focused on proper hygiene behaviour, water disinfection, well protection, etc. Both landlords and residents should also be sensitized that latrine seepage is a major source of dug-well contamination and therefore the recommended safe distances should be respected.

Our study did not investigate any association between the consumption of contaminated water from dug-wells and the prevalence of gastrointestinal diseases in the Langas area. Further studies should be done to evaluate the existence and impact of such a relationship.

\subsection{Study Limitations}

This study had two limitations. First, hydrogeological and geomorphological characteristics of the Langas area were not established. Secondly, there was no control for the hygiene practices of dug-well users as a confounding factor contributing to contamination.

\section{Ethical Considerations}

Permission was sought and obtained from the Langas area government administrators, the Eldoret Municipal Council, owners of dug-wells and the Moi University School of Medicine Institutional Research and Ethics Committee (IREC) before conducting the study.

\section{ACKNOWLEDGEMENTS}

We are very grateful to Dr. Andrew A. Obala of the Moi University Department of Medical Microbiology \& Parasitology for giving us maximum cooperation, guidance and unrestricted access to the departmental laboratory. We further remain indebted to Prof. Rose Kakai of Maseno University for her invaluable technical advice throughout the study period. Finally, we sincerely wish to thank the Moi University Community-Based Education and Service (COBES) Programme for funding the study.

\section{REFERENCES}

[1] Feachem, R (1997). Water, Wastes \& Health in Hot Climates. Norwich: John Wiley and Sons Ltd.

[2] Kimani, E.W (1999). Assessment of Faecal Contamination of Domestic Water Sources and Sanitary Practices in Langas, Eldoret. Eldoret: Moi University Community-Based Education Service Programme (COBES) Publication.

[3] Asheesh, A. et. al. (1994). A Longitudinal Study of the Relationship between Water Quality, Hy giene Behaviour and Childhood Diarrhoea in Langas, Eldoret. Eldoret: Moi University Community-Based Education Service Programme (COBES) Publication.

[4] Caincross, S. and Feachem, R (1993). Environmental Health Engineering in the Tropics: An Introductory Text, $2^{\text {nd }}$ Ed. New York: John Wiley \& Sons Inc.

[5] Collins, C.H., Lyne, M.P., and Grange, J.M (1995). Microbiological Methods. $7^{t h}$ Ed. London: Butterworth-Hei nemann Ltd.

[6] Stenstrom, T.A (1995). Tracing Bacteria from the Latrine to Ground Water in Dug-Wells. Paper presented at the Conference on Safe Water Environments, Eldoret, Kenya. August 21-23, 1995.

[7] Kimani, E.W.M. and Ngindu, A.M. Quality of Water the Slum Dwellers Use: The Case of a Kenyan Slum. J Urban Health. 2007 November; 84(6): 829-838.

[8] WHO (1996). Guidelines for Drinking Water Quality: Health Criteria and other Supporting Information. $2^{\text {nd }} E d$. Vol.2. Geneva.

[9] Water Act, Cap 372, Laws of Kenya. Government Printer. Nairobi.

[10] The Public Health Act, Cap 242, Laws of Kenya. Government Printer. Nairobi. 